\title{
CYP11B1 wt Allele
}

National Cancer Institute

\section{Source}

National Cancer Institute. CYP11B1 wt Allele. NCI Thesaurus. Code C52319.

Human CYP11B1 wild-type allele is located within 8q21 and is approximately $7 \mathrm{~kb}$ in length. This allele, which encodes cytochrome P450 11B1, mitochondrial protein, plays a role in the conversion of progesterone to cortisol in the adrenal cortex. Functional mutations in the CYP11B1 gene can result in 11-beta-hydroxylase deficiency which, in turn, causes cong enital adrenal hyperplasia. CYP11B1/CYP11B2 gene fusion causes glucocorticoid-remediable aldosteronism. 